\title{
Simultaneous Real-Time Detection of Pregnancy-Associated Plasma Protein-a and -A2 Using a Graphene Oxide-Based Surface Plasmon Resonance Biosensor [Erratum]
}

\author{
Fan SY, Chiu NF, Chen CP, Chang CC, Chen CY. \\ Int J Nanomed. 2020;15:2085-2094.
}

The title of the paper "Simultaneous Real-Time Detection of Pregnancy-Associated Plasma Protein-a and -A2 Using a Graphene Oxide-Based Surface Plasmon Resonance Biosensor" should read "Simultaneous Real-Time Detection of Pregnancy-Associated Plasma Protein-A and -A2 Using a Graphene Oxide-Based Surface Plasmon Resonance Biosensor".

This error was introduced by the Editorial staff during the typesetting process.

\section{Publish your work in this journal}

The International Journal of Nanomedicine is an international, peerreviewed journal focusing on the application of nanotechnology in diagnostics, therapeutics, and drug delivery systems throughout the biomedical field. This journal is indexed on PubMed Central, MedLine, CAS, SciSearch ${ }^{\mathbb{R}}$, Current Contents ${ }^{\mathbb{B}} /$ Clinical Medicine,
Journal Citation Reports/Science Edition, EMBase, Scopus and the Elsevier Bibliographic databases. The manuscript management system is completely online and includes a very quick and fair peer-review system, which is all easy to use. Visit http://www.dovepress.com/ testimonials.php to read real quotes from published authors. 